\title{
ANALYSIS OF PHYSICAL AND CHEMICAL COMPOSITION OF HONEY SAMPLES IN SELECTED MARKET IN IBADAN METROPOLIS
}

\author{
ADAMS, B. A, OSIKABOR, B., OLOMOLA, A. AND ADESOPE, A.A.A \\ College of Forestry Jericho Ibadan \\ Corresponding author's Email: adamcinjoy@yahoo.com
}

\begin{abstract}
The study analyzed the physical and chemical compositions of seven honey samples, which were obtained from selected markets in Ibadan metropolis. Seven samples of honey were obtained namely from sample A (Forestry honey Ibadan), Sample B (Pure honey), Sample C (Mr. honey), Sample D (Taraba honey), sample E (Sokoto honey), sample F (Saki honey) and sample $G$ (Natural honey). The variables analyzed were $\mathrm{pH}, \%$ purity, Ash content, Refractive index, Viscosity, Colour and specific gravity. The average price/litre of the honey samples $B, C$ and $G(\$ 1,250)$ was higher than samples $D, E$ and $F(\$ 666.00)$. The average \% purity of the honey samples is 92.64.Result also showed that the mean value of the variables tested namely Viscosity (4.37), Refractive index (1.49), specific gravity (1.12), pH (5.27) and $\%$ Ash content (0.35) were within the established codex standard values of honey; i.e. 1.95 $5.65,1.4000-1.9000,1.38-1.45,3.6-5.6$ and $0.20-1.03$ respectively. The result further revealed that the variables considered were within the standard set by Codex alimentrus. Improvement in processing and packaging techniques will not only enhance the acceptability of these products but also brings about higher income to the producers and marketers.
\end{abstract}

Key words: honey, market, sweetener

\section{INTRODUCTION}

Honey is a popular sweetener throughout the world; it is made by bees generally from nectars extracted from the nectarines of flowers. From ancient time, honey was used both as natural sweetener and a healing agent (National Honey Board 2002). Honey is a delicious food. It is high in carbohydrates and adds useful varieties to diets. Most honey have fructose and glucose, it is more readily digestible than cane sugar. Honey varies in taste, aroma and colour according to its source. In many societies honey has an important place in traditional food preparation and is also viewed as a source of special nutrition for children although it should not be fed to young babies. Honey is widely used as a medicine and is highly prized for this season. It is often regarded as a special tonic food to be eaten during illness. Three biological factors which account for its antibiotic activities of honey include its absorption of water which makes it capable of killing bacterial by dehydrating them. It also means honey is sterile as most micro-organism cannot survive it; presence of enzymes which produces hydrogen peroxide that kills bacteria and its acidic nature (Richard, 1999).

Honey is farmed and used all over Nigeria. Initially local farmers harvested the honey from the wild but today apiculture is a group industry in many parts of the country. Some studies on the healing effect and anti microbial activity of Nigerian's honey on burns and wounds have been reported (Adesukanmi and Oyelami, 1994). The composition of honey varies, depending mainly on the source of the nectar(s) from which is originated and to a lesser extend on a certain external factor i.e. climatic condition and bee keeping practices (White 1975). There are some confectionary products that can only be made with honey e.g. nalver (Turkey), pastili (Greece), torrene (Itally), turron (Spain), nougat (France) and 'honey drop' (Italy). Confectionery in the United States use honey in various candies. In the world today, some 1500 - 2000tons of honey are used annually in commercial confectionery. 
Others uses of honey include the manufacture of breakfast cereals, honey bread, honey butter, baby foods, packaged meat, honey preserves, dry cake mixes and a honey milk product.

It is a known fact that honey possesses nutritional health given and healing properties, hence most people do purchase any type of honey even at high cost for utilization without adequate information about the quality of such honey. This study is designed to compare the physical properties of selected honey samples in Ibadan. Specific objectives include, identification of physical properties of the selected honey samples, comparison of the properties of these honey samples with international standard (Values) and price/litre of the samples

In Nigeria, the calendar of bee activity and management of honey follows a pattern described in terms of monthly activities round the year. A brief description is given below

January: Each colony of bees has honey in store. It is time to crop the honey. Few young bees remain in the brood chamber; all comb with brood is at the centre of the single chambered hive. The double chambered frame hive will have honey in the brood chamber for the bees to feed on during the rains when nectar is scare.

February: Honey is still available in hives. Certain plants, cashew for example are in sugar.

March: Honey is hive; bee feeding normally. Pollen arrives in the hive; Queen starts laying eggs. Some wild plants are in flower e.g. acioa, pitanga cherry and citrus.

April: $\quad$ Brood chamber is filled with young bees and brood. Occasionally queen cells are found. The bees are prepared for swarming; take swarm control measure plan for new hives. Citrus and oil bean trees are now in flower.

May: $\quad$ Put out decay hives; bees are swarming. Collect swarm inspect your stock. Continue with precautionary swarming control methods. Garden vegetables are in flower, e.g. melon.

June: Peak period of swarming. Do not let swarms escape get them into proper hives.

July: $\quad$ There are few swarms issuing. Collect and feed them with sugar syrup. Plants such as Kola, cucumber, phaseoulus and other papilionaceas (garden legumes) are in flower.

August: Colonies may run out of store. Feed them with sugar. If subsistence plants like porfuluca for grown near the apiary, they will provide nectar for food.

September: The swarms collected in June and July are established and building up in strength. The queen in lay produces more young bees. Filed crops such as cassava, citrus and oil palm are flower.

October: End of rainy season. Bush or forest trees are flowering. Put queen excluder or a brood chamber and honey super on top. This prevent the queen from going into the honey super to lay eggs in the cell of the comb; the bees will ascend into the super and start building honey combs. Cassava is still in flower.

November: Bees are building honey comb as nectar arrives in the hives. Bees are making joyous hum. Cassava is still in flower.

December: Bees are ripening the honey. They notice any movement around the hive and will defend their store. Manager them calmly. (The Nigeria Field, 1985).

Honey can be identified in three ways through physical, biological and chemical methods, although the physical examination usually predominate among the methods. These often include taste (i.e it must has good taste), odour/smelling (not something badly), particles in the appearance of honey (no dead bees or wax inside), flammability by using 
matches sticks, viscosity (i.e. either tick or not) and the use of refractometer to test the moisture content and sugar content.

\section{MATERIALS AND METHODS}

Seven honey samples were randomly selected in some markets in Ibadan Oyo State, Ibadan is the largest city in southern of sahara, located within latitude $7 \mathrm{~W}$ and $9 \mathrm{~N}$ of the equator and longitude $3 \mathrm{E}$ and $\% \mathrm{E}$ of the Greenwich meridian. Ibadan falls in the rainforest zone of Nigeria and has a vegetation that supports luxuriant growth of both arable and tree crops, these crops in turns produce enough nectar that can support high population of bees in the production of honey in the area. Ibadan is inhabited mainly by Yoruba speaking people, though other tribes have settled in the areas as a result of inter-tribal marriage and economic activities.

A total of seven honey samples were randomly selected at various selected markets in Ibadan and labeled as shown below: Sample A: Forestry honey Ibadan, Sample B: Pure honey, Sample C:Mr. honey, Sample D:Taraba honey, Sample E: Sokoto honey, Sample F:Saki honey, and Sample G:Natural honey

\section{Determination of Ash}

Apparatus: Porcelain crucible, desiccators, analytical balance and a furnace

Determination: $2 \mathrm{ml}$ of he samples were weighed into a porcelain crucible. This was transferred into the muffled furnace set at $550^{\circ} \mathrm{C}$ and left for about 24 hours.

About $100^{\circ} \mathrm{C}$ in air, then room temperature in desiccators and weighed. This was done in duplicate. The percentage ash was calculated from the formula below:

$\%$ Ash content $=\frac{\text { Weight of ash }}{\text { Original weight sample }} \quad \mathrm{x} \quad \frac{100}{1}$

\section{Determination of Refractive Index}

The refractive index measurement was done with an abbe refractomet. The refractometer's sample compartment were made at room temperature $\left(20^{\circ} \mathrm{C}\right)$. the electrical conductivity measurements was done at $25^{\circ} \mathrm{C}$ using PH/Conductivity meter model 20 (Denyer instrument). The instrument was calibrated using $0.01 \mathrm{~m} \mathrm{Kcl}$ (potassium chloride solution).

\section{Determination of $\mathbf{P}^{\mathbf{H}}$}

The $\mathrm{P}^{\mathrm{H}}$ was measured using a digital $\mathrm{P}^{\mathrm{H}}$ meter model h1 8519 (Hannan Instrument)

\section{Colour Determination}

The colour of the samples was determine using the lovibond comparator.

\section{Viscosity Determination}

$20 \mathrm{ml}$ slurry of each sample was prepared and transferred into a viscopipette. The flow arate was measured after the slurry has reached the bulb of the pipette. The stop watch was used to measure the dropping from the descending of the bulb of the viscopipette. The total time taken in seconds to descend through the bulb of the seconds was taken as the time for the viscopipette was taken as th time for the flow. Viscosity was calculated by using the formula.

Volume of slurry

Time taken to flow in (s)

\section{Specific Gravity Determination}

Apparatus: $\quad$ Specific gravity bottle, stopper, water-bath

Reagent: Distilled water

Analysis: $\quad 20 \mathrm{~g}$ of honey ample was poured into specific gravity bottle to overflow, then the stopper was inserted, later incubated in water-bath at $20^{\circ} \mathrm{C}$ for 30 minutes. The bottle was 
removed from the water-bath wipped dry and weighed. Thereafter, boiled cool water was similarly treated the same way as that of sample then the specific gravity was analyzed thus:

$$
\begin{aligned}
& \mathrm{S}_{\mathrm{G}}\left[20^{0}\right]=\frac{\text { Weight of ash }}{\text { Original weight sample }} \quad \mathrm{x} \quad \frac{100}{1} \\
& \mathrm{~S}_{\mathrm{G}}\left[20^{0}\right]=\text { Specific Gravity }
\end{aligned}
$$

RESULT AND DISCUSSION

Table 1: The Physical composition of the selected honey samples in Ibadan

\begin{tabular}{llllll}
\hline Sample & Colour & $\begin{array}{l}\text { Refractive } \\
\text { index }\end{array}$ & \% Purity & Viscosity & $\begin{array}{l}\text { Spec. } \\
\text { gravity }\end{array}$ \\
\hline A & 0.86 & 1.50 & 91.68 & 5.10 & 1.11 \\
B & 1.38 & 1.49 & 91.76 & 5.30 & 1.12 \\
C & 1.25 & 1.49 & 92.85 & 4.80 & 1.12 \\
D & 0.97 & 1.50 & 96.82 & 2.90 & 1.14 \\
E & 1.29 & 1.49 & 90.46 & 4.90 & 1.11 \\
F & 1.22 & 1.49 & 90.53 & 5.00 & 1.11 \\
G & 1.28 & 1.50 & 94.38 & 5.00 & 1.14 \\
Mean & 1.19 & 1.49 & 92.64 & 4.37 & 1.12 \\
Sd & 0.20 & 0.00 & 5.24 & 1.25 & 0.00 \\
\hline
\end{tabular}

The result of the honey physical properties such as the colour, refractive index, \% purity, Viscosity and Specific gravity respectively are presented in table 1.

\section{Viscosity}

The viscosity of the honey sample falls within the range of $2.90-5.30$, mean 4.37; sample D has the lowest value of 2.90 while sample B has the highest value of 5.30. The recommended standard according to the Codex standard method of honey analysis [codes stain 1981] is 1.95 -5.65 .

\section{Refractive Index}

The refractive index of the honey sample falls within the range of $1.49-1.50$, mean 1.49 . The refractive index of the honey samples are approximately the same and fall within the range of the codex standard of $1.4000-1.9000$.

The refractive index of honey is the rapid, accurate and simple measure of its moisture content [White 1975b). Wedmore [1995] gave the following relationship between moisture content and refractive index of the honey.

Moisture content: $\quad \frac{1.7390-\log \left(\mathrm{n}_{20-1}\right)}{0.002243}$

Where $\mathrm{n}_{20}$ is the refractive index measure at $20^{\circ} \mathrm{C}$. if the refractive index is measured above $20^{0} \mathrm{C}, 0.00023$ per ${ }^{0} \mathrm{C}$ is added before using the above relationship. The honey samples tested had similar values with respect to refractive index.

\section{Specific Gravity}

The specific gravity of the honey sample have almost the same value with the mean of 1.12 and fall within the range of establish codex standard of $1.38-1.45$.

\section{Percentage Purity}

The percentage purity of the honey sample fall within the range of $90.46-96.82$ with sample E having the lowest value of 90.46 and sample D having the highest purity value of 96.82 . 


\section{Colour}

Colour is very important; it is the colour that thus more than anything else in determination of its commercial use and value. Darker honeys are most often put to industrial use while the lighter colour honeys are marketed directly for consumption. [Richard, 1999). The samples $\mathrm{B}, \mathrm{C}$ and $\mathrm{G}$ which has undergone some levels of processing have the higher value and appear brighter. The raw honey samples A,D,E and F has the lowest values signifying that they are darker then processed honey.

Table 2: The chemical composition of the selected honey samples in Ibadan.

\begin{tabular}{lll}
\hline Samples & PH & \% Ash Content \\
\hline A & 5.45 & 0.48 \\
B & 4.60 & 0.39 \\
C & 5.60 & 0.41 \\
D & 4.62 & 0.35 \\
E & 5.60 & 0.29 \\
F & 5.54 & 0.24 \\
G & 5.55 & 0.29 \\
Mean & 5.27 & 0.35 \\
SD & 0.46 & 0.03 \\
\hline
\end{tabular}

The results of the honey chemical properties are shown in table 2. The $\mathrm{pH}$ of the honey samples fall within the range of established codex standard of honey [3.6 - 5.6], pure honey has the highest acidity (4.60) while Mr. honey has the lowest acidity (5.60). These values are in comparable to the $\mathrm{pH}$ values $(3.4-6.1)$ of honey of the United State of America (White, 1975).

The mean ash content of the various honey samples are $0.35 \%$ with a range of 0.24 $0.39 \%$. Saki honey sample has the lowest ash content 0.24 while Forestry honey Ibadan has the highest ash content 0.48 . These values are in conformity with the mean ash content of U.S. honey (0.169\%) with a range of $0.20-1.028 \%$ (Adebiyi et al., 2004).

Table 3: The price $(\mathrm{N})$ per liter of the selected honey samples

\begin{tabular}{llll}
\hline & Honey samples & Quantity/litere & Price(N) \\
\hline A & Forestry honey (FCF) & 1 & 1,200 \\
B & Pure honey & 1 & 1,200 \\
C & Mr. honey & 1 & 1,00 \\
D & Taraba honey & 1 & 800 \\
E & Sokoto honey & 1 & 600 \\
F & Saki honey & 1 & 600 \\
G & Natural honey & 1 & 1,500 \\
\hline
\end{tabular}

The prices of the various honey samples per litre are represented in table 2.

Sample B, C and $\mathrm{G}$ which are processed honey are more expensive than the unprocessed honey samples with the exception of the sample A which is forestry honey. Perhaps the high cost of forestry honey could be due to the fact that forestry is a research Institute and the potential buyers are educated. Samples, D, E and F which are less expensive or cheaper than the processed ones. The higher cost of processed honey could be attributed to cost incurred at various stages of processing operation.

Honey is the highest, and sample G, which natural honey has the lowest viscosity $\mathrm{ml} / \mathrm{min}$. it is the sample $\mathrm{B}, \mathrm{A}$ and $\mathrm{F}$ that is higher than the mean viscosity mil.min of the 
honey samples. The specific gravity of the honey samples are almost the same, with the range of $(1.114-1.137)$ having the mean of $(1.120)$. The specific gravity is similar.

\section{CONCULSION AND RECOMMENDATIONS}

For Nigeria to have a place in the list of official honey exporters, it is necessary that the qualities of honey produce in the country be determined. The result of such analysis will help in the formulation of policies on bee keeping and honey products in Nigeria. Although the variables tested are just parts of properties of the honey samples. This conclusion will only b e valid only when other properties are available. The result of this study did not show any appreciable differences in the qualities of these samples. The result also showed that the honey variables considered have values which were within the value stipulated by codex standard; producers and marketers should improve their processing and packing techniques in order to have higher sales and income for both the producers and the marketers.

\section{REFERENCES}

Adebiyi, et al (2004): Chemical/Physical Characterization of Nigeria honey. Pakistan Journal of Nutrition 3 (5): $278-281$.

Adesunkanmi, K. and O.A. Oyelami (1994): The pattern and Outcome of burn injuries at Wesley Guide Hospital, Ilesha, Nigeria a review of 156 cases. J. Trop. Med. Hyg. 97: $108-112$.

National Honey Board, 2002: Honey Health and Therapeutic qualities. Retrieved January 14, 2004 from the World wide. http//www.nhb.org/infropub/month/2002/10_2002 monthly report pdf.

Richard (1999): Bee keeping as a business. Common wealth secretariat common wealth secretariat morlborogh house pull mail, London SWIYSHS United Kingdom. Pp 45-52. 